Article

\title{
Public Understanding of Climate Change as a Social Dilemma
}

\section{Stuart Bryce Capstick}

Understanding Risk Group/ Climate Change Consortium of Wales/ Tyndall Centre for Climate Change Research, School of Psychology, Cardiff University, Cardiff, CF10 3AT, UK;

E-Mail: capsticksb@cardiff.ac.uk; Tel.: +44-029-208-76262; Fax: +44-029-208-74858

Received: 6 May 2013; in revised form: 3 August 2013 / Accepted: 7 August 2013 /

Published: 13 August 2013

\begin{abstract}
Climate change is often referred to as one of the most complicated challenges facing humanity, characterised in various literatures as a social dilemma operating at multiple scales (individual, national, international). The present study considers the ways in which members of the public interpret climate change in these terms, drawing on data from multiple datasets, both qualitative and quantitative, from 1997 to 2011. As well as drawing out the nuances in participants' perspectives on the social and societal dilemmas inherent to climate change, the present study also highlights the rejoinders and resolutions proposed by people to these dilemmas. It is suggested that recognition of the ways people find to navigate these difficult issues offers some cause for optimism regarding the public's conceptualisation of, and response to, climate change.
\end{abstract}

Keywords: public perceptions; climate change; social dilemma; discourse analysis; psychology

\section{Introduction}

Across most parts of the world, public majorities recognise the basic reality of climate change and express concern about its consequences [1]. Cross-European research in 2011 found that one in five people were of the view that climate change is the single most serious problem facing the world, more so even than placed the economic situation in this category [2]. Most people are of the view that climate change is either happening now or will manifest in the near future $[3,4]$ and many believe that they have personally experienced climate change [5].

In terms of the relationship between individual behaviour and global climate change, studies furthermore suggest that there is a general acknowledgement by people of a personal obligation to help 
address climate change $[1,6-8]$; albeit that responsibility for achieving mitigation tends to be ascribed primarily to government $[9,10]$.

Despite this widespread recognition of the legitimacy and importance of climate change, there is however a strong sense in which it is also understood as a hugely complicated-perhaps even intractable - issue. In the academic literature, a number of scholars have spoken of climate change as a 'wicked' problem due to the many complex interdependencies in society that contribute to climate change and the attendant difficulty in reaching solutions [11-14]. One component of a 'wicked' problem by this formulation is the lack of a clear understanding of the cumulative impacts of collective action ([15]; see also [16]). One of the central difficulties in addressing climate change is that whilst each person's (or even each country's) emissions are individually negligible, collectively they are highly significant.

In the tradition of social psychology and behavioural economics, such a problem relates closely to the notion of a 'social dilemma'. The definition of a social dilemma is that situation in which individual action which is undesirable in collective terms (e.g., having high personal carbon emissions) nevertheless results in better personal outcomes (e.g., maintenance of a high standard of living); and yet, if most people were to act in this way, the outcome for all is undesirable $[17,18]$.

Climate change has now been conceptualised in terms of a social dilemma across a range of literature. Raihani and Aitken [19] for instance argue that, in policy terms, "climate change represents the largest social dilemma humans have ever faced". In a paper for the World Bank, Irwin [20] applies insights from economic theory to outline the multiple manifestations of social dilemmas with respect to climate change. Based on the use of survey methodology in New Zealand, Aitken et al. [21] conclude that there is a causal link between people's perceptions of a social dilemma and reduced action on climate change. Lorenzoni et al. [22] also suggest that what they term the 'worry about free-rider effect' (refraining from taking action because others are not) constitutes a significant barrier to individual action. Others have also looked at personal determinants and structural influences on behaviour within climate change-related social dilemmas [17,23].

These studies taken together illustrate that the social dilemma framework represents a powerful descriptive and analytic device for characterising the choices of individuals within a real or simulated climate change context. What is missing from the literature, however, is a systematic attempt to understand the ways in which individuals themselves understand and reason about climate change as a social dilemma. This is important because ultimately it will be people's perceptions of the climate dilemma which will influence their responses to it. As such, the present study asks the following questions. In which ways is climate change understood by people themselves as a social dilemma? What conclusions are drawn by people about individual (in)action in this context? Which resources are drawn upon to resolve and respond to the complexities inherent in the climate dilemma?

The qualitative data used in the present study to answer these questions were obtained in the UK over the period 1997-2010. These form the principal emphasis of the study. In addition, findings are presented from survey data obtained in the UK in 2011, which are used to characterise the prevalence of social dilemma beliefs. 


\section{Qualitative Data and Analytic Approach}

The present study seeks to identify commonplace themes across six qualitative datasets. Each of these was obtained from studies designed to investigate public perceptions of climate change and related issues. Whilst conceptually related, the studies were carried out independently by different research teams. The 1997, 2000, 2002, 2007 and 2010 datasets were derived from focus group/group interview studies with members of the UK public at these time points. The 2003 data was derived from individual (including paired individual) interviews. All datasets comprise verbatim transcripts of discussions. The datasets from 1997-2007 were kindly made available to the author of the present study by those involved in the original research (see Acknowledgements). Table 1 gives an overview of the projects from which source material was used for the secondary analysis carried out for the present study [8,24-27]. Further material obtained in 2010 comes from the author's own primary research [28]. The use of datasets spanning six separate projects and a 14-year period enables the present research to draw conclusions which can be considered generalisable across research settings and stable over time, in a way in which the analysis of one dataset alone (e.g., the 2010 data) would not.

Table 1. Projects from which data are (re-)analysed for the present study.

\begin{tabular}{|c|c|c|c|}
\hline $\begin{array}{c}\text { Dataset } \\
\text { year }\end{array}$ & No. participants & $\begin{array}{l}\text { Principal researcher; } \\
\text { illustrative publications }\end{array}$ & Study overview \\
\hline 1997 & 14 & $\begin{array}{l}\text { Eric Darier; } \\
\text { Darier et al. (1999) }\end{array}$ & $\begin{array}{l}\text { EU-wide project into public } \\
\text { understanding of climate change and } \\
\text { wider environmental issues }\end{array}$ \\
\hline 2000 & 19 & $\begin{array}{l}\text { Irene Lorenzoni; } \\
\text { Lorenzoni and Hulme (2009) }\end{array}$ & $\begin{array}{l}\text { Doctoral research into cross-cultural } \\
\text { perceptions of climate change }\end{array}$ \\
\hline 2002 & 24 & $\begin{array}{l}\text { Karen Bickerstaff; } \\
\text { Bickerstaff et al. (2008) }\end{array}$ & $\begin{array}{l}\text { UK project examining risk perceptions, } \\
\text { including of climate change }\end{array}$ \\
\hline 2003 & 20 & $\begin{array}{l}\text { Lorraine Whitmarsh; } \\
\text { Whitmarsh (2009) }\end{array}$ & $\begin{array}{l}\text { Doctoral research into UK climate } \\
\text { change perceptions }\end{array}$ \\
\hline 2007 & 84 & $\begin{array}{l}\text { Nick Pidgeon; } \\
\text { Butler and Pidgeon (2009) }\end{array}$ & $\begin{array}{l}\text { UK project examining perceptions of } \\
\text { climate change and energy issues }\end{array}$ \\
\hline 2010 & 47 & $\begin{array}{l}\text { Stuart Capstick; } \\
\text { Capstick (2012) }\end{array}$ & $\begin{array}{l}\text { Doctoral research into longitudinal } \\
\text { component of climate change perceptions }\end{array}$ \\
\hline
\end{tabular}

In viewing climate change as a social dilemma, a broad prior analytic framework is utilised in the analysis of the data - as such, the present discourse analysis is not intended to constitute a fully inductive approach. Rather, analytic attention is given to the ways in which a social dilemma frame manifests in the numerous specific but typical instances across the datasets. This enables a detailed exposition of how climate change is seen as a social dilemma by public participants, in a manner which is recurrent across unrelated research projects. In this way, the study aims to present findings which are characteristic of a general public understanding of the climate dilemma.

The discourse analysis used in the present study draws on that of Dryzek [29] and the social psychological tradition of Potter and Wetherell [30]. Whilst there are differences in emphasis between these approaches, each acknowledges discourses as constituting shared representations of the world: 
these are described by Potter and Wetherell as 'interpretative repertoires'. Other authors have characterised discourses similarly as 'ensembles of concepts' [31] or 'commonplaces' [32].

The work of Dryzek [29] informs the approach used in the present study for its focus upon identifying discourses through reference to their component parts and general characteristics. In line with the methodology developed by Dryzek [29] the component parts of the social dilemma discourse are presented in terms of:

(i) its ontology - the basic entities whose existence is recognised or constructed

(ii) assumptions about relationships - the nature of relationships between individuals and other social actors

(iii) agents and their motives - the social actors about whom the discourse is concerned, and the reasons ascribed to their actions

(iv) its key metaphors and rhetorical devices - the concepts and language which shape the discourse

The work of Potter and Wetherell [30] informs the study for its focus upon discourses as having function - acting as 'sense-making devices' or being used to support arguments or actions. The ways in which the social dilemma discourse is used by participants is considered as part of the reporting of results.

Where ascribing comments to participants within the results, a coding system is used in which each individual is assigned a unique code reflecting their position within a research project (' $\mathrm{P}$ ') and the year of their participation (e.g., '-2007'). For example, participant P4-2010 is participant '4' from 2010.

\section{Discourse Analysis Results}

\subsection{Summary Features}

The social dilemma discourse emphasises the inherent tensions between collective versus individual interests in the context of climate change. This may be conceptualised at various scales, from the individual to the international: for example, the value of individual action on climate change may be seen as futile where others do not act; international solutions may be viewed as unattainable due to multiple conflicting national interests.

The central and recurrent features of climate change as a social dilemma within participant talk are summarised in Table 2. Participant excerpts are subsequently utilised to discuss, firstly, the varied means by which climate change is characterised as a social dilemma and, secondly, the ways in which participants propose responses and resolutions to these dilemmas. 
Table 2. Characteristic features of climate change as a social dilemma.

\begin{tabular}{|c|c|}
\hline Discourse feature & Manifestation within social dilemma discourse \\
\hline $\begin{array}{l}\text { Ontology (basic entities } \\
\text { recognised) }\end{array}$ & - Climate change as a social and societal problem \\
\hline $\begin{array}{l}\text { Assumptions about } \\
\text { relationships }\end{array}$ & $\begin{array}{l}\text { - Conflicts between collective and individual interests } \\
\text { - Cooperation and reciprocity (both by their absence and as a way of } \\
\text { responding to dilemmas) }\end{array}$ \\
\hline Agents and their motives & $\begin{array}{l}\text { - People and institutions at all scales-in particular individuals, } \\
\text { national governments, nations } \\
\text { - Primary motivation of self-interest }\end{array}$ \\
\hline $\begin{array}{l}\text { Key metaphors and } \\
\text { rhetorical devices }\end{array}$ & $\begin{array}{l}\text { - Social systems as 'Darwinian'-e.g., survival of the fittest, } \\
\text { competition between social actors } \\
\text { - Global 'villains' (e.g., USA, China) and 'minnows' (e.g., England) } \\
\text { - Climate change as a 'trap'-multiple competing interests at odds } \\
\text { with collective public good } \\
\text { - Free-riding - ability and tendency of social actors to pursue own } \\
\text { interests irrespective of others } \\
\text { - 'Drop in the ocean'—unilateral action pointless in and of itself } \\
\text { - 'Doing your bit'—individual action in a collective context } \\
\text { - 'Everyone'/‘everybody' acting - collective action in response to a } \\
\text { social dilemma }\end{array}$ \\
\hline
\end{tabular}

The existence of, and problem of responding to climate change is argued in a number of places to derive directly from the nature of humanity and human society, where these are seen as being inherently self-interested and ill-suited to responding to large-scale collective problems. It is in this context that in a year 2000 group participant P5-2000 talks of being "pessimistic" about the ability of "mankind" to respond to climate change; likewise in 2010, participant P20-2010 argues that they are not optimistic due to "human beings" being self-interested:

I tend to get a bit of a pessimistic outlook on mankind... as far as being able to get together and make independent decisions for the benefit of everybody without self-interest coming into it... this is the big problem and probably one of the biggest problems for mankind. (P5-2000)

It's going to come down in the end to ordinary human beings either helping things, climate change... to all get working together... but I don't know whether that's possible. I'm not very optimistic really, because I think self-interest will take the place of a great many people, in their thoughts. You ask people: 'would you be prepared to do all this sort of- for somebody else?' And the answer... is probably 'no', in their minds. (P20-2010)

Where this type of reasoning is contextualised to the national and international level, such self-interest is portrayed as problematic particularly where some countries are seen as more vulnerable than others - this is illustrated by the following argument of P5-1997:

If you're asking every country in the world, all the big powers to do something about it, if some countries or [regions] are not as badly affected, they're not going to be as forthcoming are they [in contrast to] if everybody's in the same boat. 
Equally, in 2002 an exchange between participants asserts the view that those with 'power' and 'money' are bound not to be concerned with 'everyone else':

P24-2002: Those that are in power and have got the money and all the rest of it will find a way of being above everybody else and they won't bother too much about those that are getting drowned.

P23-2002: If it got flooded they'd probably build a house on stilts or something, and it's tough for the person down there who's got nothing, they've still got their nice big house and everything... and [expletive] everyone else basically.

At the international level, the archetypal self-interested nation referred to-seen as central to the international social dilemma of climate change - is the United States of America (although China is also frequently referred to). For example in 1997, P4-1997 argues that problems with international agreement on climate change have arisen due to "America sticking their heels in". P7-2002 similarly refers to the USA being characteristically obstructive, where he asserts "I don't think there's the will politically within the world to do much... the biggest polluter being America, they're just not prepared to do anything". Elsewhere other global 'villains' are pointed out as culpable both for causing and failing to address climate change - indeed, the idea that individual nations' self-interests lead to lack of global action, is widespread across all datasets. This is illustrated by the following excerpts:

[T] he Russian countries... don't seem to have restrictions on how much... fossil [fuels] they use. (P7-2002)

China, they're just pushing out more... India is doing its best as well [to pollute]... Argentina, Brazil, they're cutting the forests down... (P66-2007)

[D]eveloping countries... like India and China and places like that... say 'well, why should we give a [expletive]?' (P21-2003)

The idea that climate change represents a large-scale social dilemma leads to particular arguments being made about the value of national responses. Participants commonly argue that a national response is irrelevant or ineffective in and of itself in the context of inaction by others. This is illustrated by the following four excerpts from the 2000, 2002, 2007 and 2010 datasets:

What's the good of a little country like England... doing something to help the environment and then the whole of Europe or Russia or China... does something completely the opposite? ...it's almost a waste of time. (P5-2000)

It's a world problem... and, you know, the top countries that are polluting the world can't agree to actually do very much about it. So irrespective of what we might do on a very small island called Britain we're not going to make a lot of difference. (P7-2002)

If we do something and other countries don't it's pointless. Pointless. (P66-2007)

I'm conscious there are many countries in the world who are probably larger contributors to the sources of global warming that... do nothing... [I]t makes me wonder, given the balance of population between the Western world and the wider world, whether in fact it's just a drop in the ocean. (P16-2010) 
That the phrases 'waste of time', 'pointless', and 'drop in the ocean' are used here, draws attention to the potentially fatalistic consequences of a social dilemma perspective of climate change in the context of international action. Furthermore, even at the very small-scale, participants often emphasise the inequities and inconsistencies of causes of and responses to climate change. For example, it is not uncommon for discussions of personal action around climate change to relate to everyday issues such as recycling and use of resources, and here questions of interpersonal social dilemmas emerge recurrently. At the individual level, the problem of 'free-riding' is thus construed as a social dilemma, whereby the lack of action by some is seen to limit the value of action by others. This is illustrated by the following excerpts from 2002 and 2003:

The hardest part about it... you'll always get a certain amount of people that just won't be bothered at all like everything else... (P21-2002)

I sometimes feel we're wasting our time, because so many other people don't do things... I sometimes wonder if it's worth it. (P7-2003)

The perspective that individual action is irrelevant may even be extended to argue that - in the context of a social dilemma-acting in a pro-environmental manner is essentially foolish, as propounded by P23-2007:

I read last week, there was a family and they decided they were going to go completely green, they weren't go to have a car, they weren't going to do this, they were going to do that... and I thought, more fool you. Because everyone else is, you know, what, what are you doing, you're making your life harder, what are you achieving? I know you're doing your little bit, but what are you really... what difference are you making?

\subsection{Responding to Climate Change as a Social Dilemma}

As many of the excerpts above demonstrate, social dilemma perspectives on climate change are commonplace and tend to be associated with a sense of resignation, fatalism and lack of agency. Nevertheless, this is not an inevitable reaction to the social dilemma framing-indeed, there are striking instances of participants proposing resolutions and responses to characteristic social dilemmas in both pragmatic and normative terms.

One rhetorical device frequently employed is the notion of 'doing your bit'. This is used both to argue for a social obligation and also as having worth as part of a cumulative effort. For example, P17-2003 directly counters the suggestion that there is 'no point' in individual action in the absence of government intervention, by drawing on the idea both of personal obligation and as part of a wider effort:

Moderator: So... the fact that the government isn't taking more action... does that make you feel there's no point in individuals, yourself, making an effort to cut down, or...?

P17-2003: No, I would still do my part if I could, because that's the only way I feel I can help... I suppose I'm thinking, yeah, it's only a very small part, but if other people do it as well, it should make a difference. It certainly should. And if you can get people to do that worldwide, it would make a big difference. 
The simple entreaty to 'do your bit' recurs frequently in other datasets. Thus for example in 2007, P6-2007 suggests that "we can all try and do our bit", P23-2007 that "we should all do our bit", P67-2007 that "you should... just... try and, you know, do your bit as it were", and P84-2007 argues that there is a purpose (the term 'can' is used in this respect) in individual action: "humans can do something... you can do your own little thing".

Likewise, across the 2010 data this idea recurs - both in normative (what one 'should' do) and pragmatic terms (as contributing to a whole). For example, participants P14-2010 and P23-2010 both suggest that individual contributions lead to a cumulative impact (the latter in response to the more fatalistic perspective of another participant); and P25-2010 asserts an obligation to act given the UK has a high relative ('per capita') impact:

I think if everybody did their bit... it could make the world a better place... if everyone did their own little bit towards helping the environment. (P14-2010)

P20-2010: We can't do very much as individuals.

P23-2010: Well, a voice is what we are and we can think with our own private lives and I do feel that if everybody does a bit, it's a lot.

All we can do is do our bit and as we are one of the nations that per capita consumes an awful lot, it's very necessary for us to do that. (P25-2010)

P27-2010 also argues for individual action on the basis of both a normative ('a responsibility') and cumulative ('collectively') argument: "if everybody does something, then collectively it should be more powerful than anything else. And I [think] everyone's got a responsibility to do something".

As with P27-2010's reference to 'everybody' and 'everyone', the cumulative worth of multiple individual action is affirmed in many places across the datasets. This is often revealed through the use of similar language - for example, P4-2002 argues that "if we all stood together... there is the wherewithal to change things", P12-2002 that "if everybody did one small thing... that's going to help", P24-2007 that "everybody should be involved" and P4-2010 that individual action would be meaningful "if everyone did it".

Even where it may not be clear that individual action occurs within a cumulative context, participants argue for its occurrence nonetheless - for example, a participant within the 2000 dataset asserts that "trying to get a disparate group like Europe... to do something about climate change is going to be very difficult... so I think we've got to revert back to what is achievable within our own compass" (P1-2000).

The argument for individual action despite - indeed because of - the social dilemma character of climate change is asserted by two participants (P11-2007 and P13-2007) in direct response to another participant's (P17-2007) repeated suggestions that this has little value, in the following 2007 exchange (part of this dialogue has previously been reported in [6]). This is revealing for the rejoinders offered to lines of reasoning characteristic of the climate change social dilemma in several different guises:

P17-2007: Do you think we honestly make any difference ourselves by burning low energy lamps and switching...?

P13-2007: If everyone did it, yeah.

P17-2007: And don't leave your television set on standby at night? 
P13-2007: Yeah, if everyone did it.

P17-2007: Do you think we make a difference to that?... When you see what... the United States and China are doing?

P13-2007: It'd still make a difference wouldn't it.

P17-2007: We're just fiddling about we are.

P11-2007: Yeah, but if 60 million people in the UK start it, maybe it'll become a trend. You know, somebody's got to start it somewhere. If we can be the world leaders in energy efficiency, we can set an example, maybe other countries will say 'Well, it works in the UK, maybe we can follow their lead'.

P13-2007: Better than 60 million people not doing it.

Exchanges such as the one presented above illustrate the ways in which both a social dilemma framing and an 'anti'-dilemma counter position serve functions in interaction, and, as importantly, support rationales either for action or inaction on climate change at the personal level. In the case of P17-2007's argument — characteristic of a social dilemma interpretation — action on climate change at a personal or national level is irrelevant and ineffective. However, the arguments made by P13-2007 and P11-2007 present individual or single nation action as having purpose and meaning even in the explicit context of a climate change social dilemma.

An exchange between participants within the 2010 data also demonstrates how the types of arguments outlined above play out in both normative and pragmatic terms, and in the context of individual and national level action. As in the 2007 exchange above, arguments are made by one participant (P37-2010) that the inaction of business precludes an obligation for individual action. In response, participant P41-2010 directly criticises the social dilemma framing presented ('why should I do it because they're not doing it?') and argues that action is required primarily for normative reasons ('because it's the right thing'), drawing on the idea of 'doing your bit' to do so. (A response in turn from P37-2010 is also included, in which the notion of 'human nature' is used to argue again for a more fatalistic social dilemma perspective.)

P37-2010: I think business gets away with murder... We've all been forced to recycle with our councils [with] the wheelie bins for how long now? But... shouldn't it be the same for everyone?

P41-2010: But you can't go "well why should I do it because they're not doing it?" that argument... you should do it because you should do it, not because somebody else is doing it or not doing it. You should do it because it's the right thing... You can't blame everybody else, you've got to take personal responsibility and say: even if everyone else is still messing up, I, me, I know I'm doing my bit, and if everybody...

P37-2010: But I can't help who I am, and human nature dictates to me, I think: well why am I doing it and my firm that I work for isn't even doing it?

This exchange illustrates that whilst the social dilemma framing has some force in argument, participants are nevertheless able to draw on resources to counter it in ways which acknowledge the framing, whilst at the same time, directly challenge its assumptions and implications. 


\section{Quantitative Data and Analytic Approach}

The quantitative data reported in the present study formed part of an online survey carried out between 7th and 15th February 2011 designed to obtain public perceptions of climate change [28]. Quota sampling [33] was used to obtain a representative sample by age and gender according to 2001 UK Census estimates; the final sample comprised 500 respondents. The survey was administered by a market research company through their pre-existing online respondent panel.

Four items were included which were intended to reflect the conceptualisation of climate change as a social dilemma, including means of responding to this. Two of these were designed and utilised in previous research [26,34]. Two further items were original and were constructed for the purpose of gauging public perceptions concerning the social contexts of climate change. Participants were asked to what extent they agreed or disagreed, on a five-point scale, to each item. The items used were:

- The actions of a single person don't make any difference in tackling climate change.

- There is no point in me doing anything about climate change because no-one else is.

- Climate change is hard to address because there are so many people on the planet pulling in different directions.

- If each of us did our bit to help, we could put an end to the problems of climate change.

Responses to these items are used to indicate the prevalence of views typical of the social dilemma framings of climate change.

\section{Survey Findings}

The results of the survey suggest that the majority of respondents are of the view that climate change possesses the characteristics of a social dilemma, as reflected by responses to item 'Climate change is hard to address because there are so many people on the planet pulling in different directions'. Over three-quarters (79\%) of people agreed or strongly agreed with this proposition; with only $3 \%$ disagreeing. However, where item wording conveys the implications of this in terms of the lack of value or relevance of individual action, levels of agreement are far lower. Less than a third (30\%) agreed or strongly agreed that 'The actions of a single person don't make any difference in tackling climate change' (41\% disagreed or strongly disagreed) and only around one in eight respondents (13\%) were of the view that 'There is no point in me doing anything about climate change because no-one else is' (55\% disagreed or strongly disagreed).

With respect to the proposition reflecting the notion portrayed by a number of participants in the qualitative component to the research - that cumulative action ('doing one's bit') would successfully address climate change, there was a high level of agreement relative to disagreement ( $41 \%$ versus $24 \%$ ) with around a third of respondents (33\%) stating that they neither agreed nor disagreed with this statement.

The full results for each of these items are given in Table 3. 
Table 3. Prevalence of social dilemma perspectives.

\begin{tabular}{|c|c|c|c|c|c|c|c|}
\hline \multicolumn{8}{|c|}{ Percentage responding } \\
\hline & $\begin{array}{c}\text { Strongly } \\
\text { disagree } \\
1\end{array}$ & $\begin{array}{c}\text { Disagree } \\
2\end{array}$ & $\begin{array}{c}\text { Neither/ } \\
\text { nor } \\
3\end{array}$ & $\begin{array}{c}\text { Agree } \\
4\end{array}$ & $\begin{array}{c}\text { Strongly } \\
\text { agree } \\
5\end{array}$ & $\begin{array}{c}\text { Mean } \\
\text { (SE, SD) }\end{array}$ & $\begin{array}{l}\text { Don't know/ } \\
\text { No opinion }\end{array}$ \\
\hline $\begin{array}{l}\text { The actions of a single } \\
\text { person don't make any } \\
\text { difference in tackling } \\
\text { climate change }\end{array}$ & 12 & 29 & 28 & 20 & 10 & $\begin{array}{c}2.87 \\
(0.05,1.17)\end{array}$ & 1 \\
\hline $\begin{array}{l}\text { There is no point in me } \\
\text { doing anything about } \\
\text { climate change because } \\
\text { no-one else is }\end{array}$ & 21 & 34 & 30 & 9 & 4 & $\begin{array}{c}2.39 \\
(0.05,1.05)\end{array}$ & 2 \\
\hline $\begin{array}{l}\text { Climate change is hard } \\
\text { to address because there } \\
\text { are so many people on } \\
\text { the planet pulling in } \\
\text { different directions }\end{array}$ & 1 & 3 & 18 & 51 & 27 & $\begin{array}{c}4.01 \\
(0.04,0.79)\end{array}$ & 1 \\
\hline $\begin{array}{l}\text { If each of us did our bit } \\
\text { to help, we could put an } \\
\text { end to the problems of } \\
\text { climate change }\end{array}$ & 8 & 16 & 33 & 32 & 9 & $\begin{array}{c}3.18 \\
(0.05,1.07)\end{array}$ & 2 \\
\hline
\end{tabular}

Note: The percentages in the table may not always add up to $100 \%$ due to rounding.

\section{Discussion}

The idea that climate change is a complex social dilemma has previously been recognised in the literature $[19,20]$. Research with members of the public has also suggested that this is reflected in people's own understanding of climate change. Lorenzoni et al. [22] for example speak of participants' reference to what they term a 'free-rider effect' and Fischer et al. [35] argue that participants express strong doubts about others' and society's capacity for cooperation to respond to climate change. Other work has also applied the social dilemma paradigm to understand and test behaviour and attitudes in the context of climate change [17,23]. However, despite the strong and consistent emphasis which has been placed upon the idea of climate change as a social dilemma, few previous studies have attempted to elucidate in any detail the ways in which this permeates public understanding of climate change.

The discourse analysis of the present study shows that the climate dilemma is considered to relate to fundamental (even 'Darwinian') aspects of human nature and human society, and as originating from the inherently self-interested motivations of individuals and nations. Given the distributed and diffuse character of climate change as a social problem, it is argued that standalone action is ineffectual, particularly where this is not reciprocated. Participants' perspectives on the climate dilemma often give it the appearance of an intractable problem - and indeed the language often used by participants reflects a sense of resignation and fatalism concerning the capacity for individuals and society as a whole to respond to climate change. It is clear from the survey data that elements of a social dilemma in the context of climate change are recognised by the majority of respondents. Furthermore, and as 
Bickerstaff et al. [8] point out, even though members of the public recognise the role of individual behaviour in contributing to climate change, they may be unconvinced that personal action will be effective in addressing climate change given a wider social context in which others are not seen as playing their part. Likewise Butler [6] argues that people often struggle with the placing of responsibility at the individual level in the context of climate change, given their actual experiences of wider social processes.

And yet - among participants' perspectives, strong arguments can also be found for action in spite of - even because of - the social dilemma nature of climate change. One of the principal grounds for responding at the individual (or individual nation) level is that, whilst this may in isolation be unimportant, this will be meaningful at a cumulative level. This perspective corresponds with what Hobson and Niemeyer [36] observe in the context of public understanding of climate change adaptation-where they refer to 'collective and other-focussed endeavour' as a motivation of individuals, in which there is explicit recognition of the wider social context. Wolf et al. [37] similarly refer to a 'communitarian' character in many participants' perspective on climate change, in which people emphasise personal responsibility as part of a 'greater collective' - these authors conclude that such a view was prevalent among those participating in their research in Canada. In psychological terms, this emphasis on the importance of combined effort corresponds to ideas of collective (rather than individual) efficacy and agency. Koletsou and Mancy [38] have indeed argued that perceptions of collective action and outcomes are likely to be critical in determining responses to climate change, whilst noting that there is little empirical research in this area.

As well as conceptualising individual action as having instrumental value as part of a cumulative effort, there is also a strong normative focus in a number of participant remarks-reference is made for example to what one 'should' do. This sense of an obligation to act has in the literature been termed 'actionable' responsibility [39] including in the context of climate change [8]. Actionable responsibility can be described as involving the making of connections between moral values and one's own behavioural context, leading to a perceived duty to act. The discourse analysis of the present study suggests that this may occur even where there is not felt to be equivalent action by others. These types of perspective resonate with Myers' [32] contention that people express a personal obligation to act on behalf of others as well as oneself in the context of social and moral dilemmas. With respect to climate change in particular, it has furthermore been argued that personal action has come to be increasingly moralised [6] and that the ascription of personal responsibility for environmental issues as a 'citizen-consumer' has been widely promoted within contemporary political agendas [40].

The present study has argued that rhetorical devices such as 'doing one's bit' can serve as rejoinders to the disempowering character of the climate dilemma. I suggest that many of the arguments in favour of action on climate change, as presented above, provide some basis for optimism about public responses to climate change. Despite recognising the complexities and the societal and interpersonal impediments to change, the value of individual action is nevertheless affirmed by people. This is a phenomenon rarely recognised in the literature, as many studies have instead tended to focus upon 'barriers' to behaviour change as manifest in public attitudes [22,41,42] rather than people's own approaches to circumventing or challenging these. The survey responses indicate nevertheless that such a perspective is relatively widespread: more people were in agreement that cumulative action ('if each of us did our bit') could effectively address climate change, than disagreed with this 
proposition; and respondents more often disagreed with survey propositions implying that individual action was futile within a social dilemma.

This is not to say that the 'anti'-dilemma perspectives expressed are without implications of their own. Hobson [43] has argued for example that whilst the commonplace entreaty to 'do your bit' can lead to positive outcomes, it also promotes a very narrow form of environmental responsibility in which 'the environment' is viewed as something external to feel guilty about or obliged towards (see also [44,45]). Indeed, it may be argued that the sorts of arguments as presented by participants in the present study are made almost exclusively within a context in which 'small actions' are performed as part of an otherwise unaffected way of life [46]. This, Hobson argues [43,47] plays down the very real political and collective nature of the challenges faced. The idea that even the cumulative impact of many such small actions is meaningful in real terms has also been challenged-MacKay (2009) for example argues that "the mantra 'little changes can make a big difference' is bunkum, when applied to climate change" [48]; and Wolf et al. [37] draw attention to numerous other studies that question the effectiveness of individual action and people's ability to enact change. Luque [49] furthermore argues that unless 'doing one's share' takes as its focus an intention to alter structural conditions (as opposed to undertaking only limited behavioural measures) then the wider context within which people act will remain unchanged.

It should also be borne in mind that arguments made in favour of collective action (and, as part of this, for the significance of individual action within a collective context) may be aligned with underlying values or worldviews that are subscribed to by some people more than others. A substantial corpus of studies has now demonstrated that 'self-transcendent' values, in which a concern for the welfare of others is a guiding principle in one's life, tend to be associated with a willingness to act pro-environmentally and to consider climate change an important issue [50-53]. Likewise, the holding of an 'egalitarian' worldview in which collective action and decision-making are seen as imperative for addressing problems, tends also to be associated with a perception of the importance of climate change [54-56]. It could be the case, therefore, that the advocacy by some participants for action on climate change in the context of a social dilemma may be related to their particular outlooks on life manifesting within assertions made in the research context.

\section{Implications for Future Research and Public Engagement}

Future research might examine how arguments made in favour of action in the context of the climate dilemma, may be supported and advanced into new terrain. Whilst there has been a pronounced trend in recent years towards the promotion of pro-environmental behavior action within an individualized and self-interest frame [44,45] what has been less explored is an understanding of how individual action can be meaningfully incorporated within the context of collective action. Some recent research has suggested that a perception of efficacy at the collective level (the understanding that collective effort is both possible and meaningful) can be influential in promoting pro-environmental behaviour [38,57] however this requires to be examined in more detail. The use of linguistic cues congruent with a 'common interest' frame [51] might be one practical way in which the types of arguments advanced by participants in the present study could be developed and tested as part of structured communication. It would be of interest in particular to examine whether such an 
emphasis on common interest and collective effort would resonate broadly across different worldviews and personal outlooks, or whether such emphases would have a more limited appeal.

A second area warranting further research attention is that concerning the conceptualization of social dilemmas within climate change adaptation. The present study has been limited to considering the ways in which participants understand climate change as a social dilemma in terms of mitigatory responses at the personal, national or international level. There is however increasing recognition that public engagement in climate change adaptation will be required now and in the future [58,59] and that, as with mitigation, collective responses are also required for adaptation [60,61]. Whilst research studies have begun to examine public perceptions of climate change adaptation (e.g., [62-65]) the specific means by which adaptation may be understood by people to constitute a social dilemma are, however, yet to investigated. The sorts of decisions presented by adaptation-for example, whether to invest in flood defences at the homeowner level or for there to be an expectation that this be the responsibility of government [66] — might indeed be expected to be characterized by similar tensions between individual and collective action as is found with mitigation.

\section{Conclusions}

Climate change is recognised and interpreted as a social dilemma by members of the public, as shown by the analysis of multiple qualitative datasets over the period 1997-2010. Study participants emphasise the multiple conflicts between collective and individual interests, seen to be driven by factors such as self-interest and free-riding. At the same time, arguments are put forward which respond to the framing of climate change as a social dilemma in both normative and pragmatic terms, emphasising the value of cumulative effort and personal responsibility. Quantitative survey data are used to demonstrate that both types of perspective are widespread within a representative sample. It is argued that the resources used to respond to social dilemmas by participants themselves represent a foundation from which to build a constructive engagement with climate change.

\section{Acknowledgments}

This study was possible thanks to the generous provision by researchers in five projects of their qualitative data for secondary analysis. I would like to thank the following for enabling the use of this data and for additional assistance with interpretation: Eric Darier, Irene Lorenzoni, Nick Pidgeon, Lorraine Whitmarsh, Catherine Butler, Karen Parkhill. I would also like to thank two anonymous reviewers for constructive comments that improved the paper.

The research was undertaken as part of the doctoral studies of the author under the supervision of Nick Pidgeon and Karen Henwood at Cardiff University. The research was funded through the ESRC Climate Leader Fellowship of Nick Pidgeon and through the support of the Climate Change Consortium of Wales.

\section{Conflict of Interest}

The author declares no conflict of interest. 


\section{References}

1. Brechin, S.; Bhandari, M. Perceptions of climate change worldwide. WIREs Clim. Change 2011, 2, 871-885.

2. Eurobarometer. Climate Change Report: Special Eurobarometer 372; Research report for the European Commission. Available online: http://ec.europa.eu/public_opinion/archives/ebs/ ebs_372_en.pdf (accessed on 22 April 2013).

3. Spence, A.; Poortinga, W.; Pidgeon, N. The psychological distance of climate change. Risk Anal. 2012, 32, 957-972.

4. Leiserowitz, A.; Maibach, E.; Roser-Renouf, C.; Feinberg, G.; Howe, P. Climate Change in the American Mind: Americans' Global Warming Beliefs and Attitudes in September, 2012; Yale University and George Mason University, Yale Project on Climate Change Communication: New Haven, CT, USA, 2012. Available online: http://environment.yale.edu/climate/files/ClimateBeliefs-September-2012.pdf (accessed on 22 April 2013).

5. Myers, T.; Maibach, E.; Roser-Renouf, C.; Akerlof, K.; Leiserowitz, A. The relationship between personal experience and belief in the reality of global warming. Nature Clim. Change 2013, 3, 343-347.

6. Butler, C. Morality and Climate Change: Is leaving your TV on standby a risky behaviour? Environ. Values 2010, 19, 169-192.

7. Wells, V.; Ponting, C.; Peattie, K. Behaviour and climate change: Consumer perceptions of responsibility. J. Mark. Manag. 2011, 27, 808-833.

8. Bickerstaff, K.; Simmons, P.; Pidgeon, N. Constructing responsibilities for risk: Negotiating citizen-state relationships. Environ. Plan. A 2008, 40, 1312-1330.

9. Pidgeon, N. Public understanding of, and attitudes to, climate change: UK and international perspectives and policy. Clim. Policy 2012, 12 (Suppl. 1), S85-S106.

10. Spence, A.; Venables, D.; Pidgeon, N.; Poortinga, W.; Demski, C. Public Perceptions of Climate Change and Energy Futures in Britain: Summary Findings of a Survey Conducted in January-March 2010; Technical Report (Understanding Risk Working Paper 10-01); Understanding Risk Group, School of Psychology, Cardiff University: Cardiff, UK, 2010. Available online: http://psych.cf.ac.uk/understandingrisk/docs/final_report.pdf (accessed on 22 April 2013).

11. Turpenny, J.; Lorenzoni, I.; Jones, M. Noisy and definitely not normal: Responding to wicked issues in the environment, energy and health. Environ. Sci. Policy 2009, 12, 347-358.

12. Hulme, M. Why We Disagree about Climate Change; Cambridge University Press: Cambridge, UK, 2009.

13. Levin, K.; Cashore, B.; Bernstein, S.; Auld, G. Playing it Forward: Path Dependency, Progressive Incrementalism, and the "Super Wicked" Problem of Global Climate Change. In IOP Conference Series: Earth and Environmental Science, 6(50), Proceedings of the Climate Change: Global Risks, Challenges and Decisions Congress, Copenhagen, Denmark, 10-12 March 2009.

14. Lazarus, R. Super wicked problems and climate change: Restraining the present to liberate the future. Cornell Law Rev. 2009, 94, 1153-1233.

15. Carley, M.; Christie, I. Managing Sustainable Development; Earthscan: London, UK, 2000.

16. Rittel, H.; Webber, M. Dilemmas in a general theory of planning. Policy Sci. 1973, 4, 155-169. 
17. Van Lange, P.; van Vugt, M.; Meertens, R.; Rutter, R. A social dilemma analysis of commuting preferences: The roles of social value orientation and trust. J. Appl. Soc. Psychol. 1998, 28, 796-820.

18. Dawes, R. Social dilemmas. Annu. Rev. Psychol. 1980, 31, 169-193.

19. Raihani, N.; Aitken, D. Uncertainty, rationality and cooperation in the context of climate change. Clim. Change 2011, 108, 47-55.

20. Irwin, T. Implications for Climate-Change Policy of Research on Cooperation in Social Dilemmas; Background Paper to the 2010 World Development Report (Policy Research Working Paper 5006); The World Bank: Washington, DC, USA, 2009. Available online: http://elibrary.worldbank.org/content/workingpaper/10.1596/1813-9450-5006 (accessed on 22 April 2013).

21. Aitken, C.; Chapman, R.; McClure, J. Climate change, powerlessness and the commons dilemma: Assessing New Zealanders' preparedness to act. Global Environ. Change 2011, 21, 752-760.

22. Lorenzoni, I.; Nicholson-Cole, S.; Whitmarsh, L. Barriers perceived to engaging with climate change among the UK public and their policy implications. Global Environ. Change 2007, 17, 445-459.

23. Milinski, M.; Sommerfeld, R.; Krambeck, H.; Reed, F.; Marotzke, J. The collective-risk social dilemma and the prevention of simulated dangerous climate change. Proc. Natl. Acad. Sci. USA 2007, 105, 2291-2294.

24. Darier, E.; Gough, C.; de Marchi, B.; Funtowicz, S.; Grove-White, R. Between democracy and expertise? Citizens' participation and environmental integrated assessment in Venice (Italy) and St. Helens (UK). J. Environ. Policy Plan. 1999, 1, 103-120.

25. Lorenzoni, I.; Hulme, M. Believing is seeing: Laypeople's views of future socio-economic and climate change in England and in Italy. Public Underst. Sci. 2009, 18, 383-400.

26. Whitmarsh, L. Behavioural responses to climate change: Asymmetry of intentions and impacts. J. Environ. Psychol. 2009, 29, 13-23.

27. Butler, C.; Pidgeon, N. Media Communications and Public Understanding of Climate Change: Reporting Scientific Consensus on Anthropogenic Warming. In Climate Change and the Media; Boyce, T., Lewis, J., Eds.; Peter Lang: Oxford, UK, 2009.

28. Capstick, S. Climate Change Discourses in Use by the UK Public: Commonalities and Variations over a Fifteen Year Period. Ph.D. Thesis, Cardiff University, Cardiff, UK, 2012.

29. Dryzek, J. The Politics of the Earth: Environmental Discourses; Oxford University Press: Oxford, UK, 1997.

30. Potter, J.; Wetherell, M. Discourse and Social Psychology: Beyond Attitudes and Behaviour; Sage: London, UK, 1987.

31. Hajer, M.; Versteeg, W. A decade of discourse analysis of environmental politics: Achievements, challenges, perspectives. J. Environ. Policy Plan. 2005, 7, 175-184.

32. Myers, G. Commonplaces in risk talk: Face threats and forms of interaction. J. Risk Res. 2007, 10, 285-305.

33. Hewson, C. Conducting research on the internet. Psychologist 2003, 16, 290-293.

34. Whitmarsh, L. A Study of Public Understanding of and Response to Climate Change in the South of England. Ph.D. Thesis, University of Bath, Bath, UK, 2005. 
35. Fischer, A.; Peters, V.; Va'vra, J.; Neebe, M.; Megyesiet, B. Energy use, climate change and folk psychology: Does sustainability have a chance? Results from a qualitative study in five European countries. Global Environ. Change 2011, 21, 1025-1034.

36. Hobson, K.; Niemeyer, S. Public responses to climate change: The role of deliberation in building capacity for adaptive action. Global Environ. Change 2011, 21, 957-971.

37. Wolf, J.; Brown, K.; Conway, D. Ecological citizenship and climate change: Perceptions and practice. Environ. Polit. 2009, 18, 503-521.

38. Koletsou, A.; Mancy, R. Which efficacy constructs for large-scale social dilemma problems? Individual and collective forms of efficacy and outcome expectancies in the context of climate change mitigation. Risk Manag. 2012, 13, 184-208.

39. Eden, S. Individual environmental responsibility and its role in public environmentalism. Environ. Plan. A 1993, 25, 1743-1758.

40. Barr, S.; Gilg, A.; Shaw, G. Citizens, consumers and sustainability: (Re)Framing environmental practice in an age of climate change. Global Environ. Change 2011, 21, 1224-1233.

41. Gifford, R. The dragons of inaction: Psychological barriers that limit climate change mitigation and adaptation. Am. Psychol. 2011, 66, 290-302.

42. Swim, J.; Clayton, S.; Doherty, T.; Gifford, R.; Howard, G.; Reser, J.; Stern, P.; Weber, E. Psychology and Global Climate Change; Addressing a Multifaceted Problem and Set of Challenges; American Psychological Association: Washington, DC, USA, 2010. Available online: http://www.apa.org/science/about/publications/climate-change.aspx (accessed on 22 April 2013).

43. Hobson, K. Reasons to be cheerful: Thinking sustainably in a (climate) changing world. Geogr. Compass 2008, 2, 199-214.

44. Paterson, M.; Stripple, J. My Space: Governing individuals' carbon emissions. Environ. Plan. D Soc. Space 2010, 28, 341-362.

45. Maniates, M.F. Individualization: Plant a tree, buy a bike, save the world? Global Environ. Polit. 2001, 1, 31-52.

46. Crompton, T.; Thogersen, J. Simple and Painless? The Limitations of Spillover in Environmental Campaigning; WWF: London, UK, 2009. Available online: http://www.wwf.org.uk/wwf_articles.cfm?unewsid=2728 (accessed on 22 April 2013).

47. Hobson, K. Bins, bulbs and shower timers: On the 'techno-ethics' of sustainable living. Ethics Place Environ. 2006, 9, 335-354.

48. MacKay, D. Sustainable Energy-without the Hot Air. Available online: http://www.withouthotair.com (accessed on 22 April 2013).

49. Luque, E. Researching environmental citizenship and its publics. Environ. Polit. 2005, 14, 211-225.

50. Poortinga, W.; Spence, A.; Whitmarsh, L.; Capstick, S.; Pidgeon, N. Uncertain climate: An investigation of public scepticism about anthropogenic climate change. Global Environ. Change 2011, 21, 1015-1024.

51. Crompton, T. Common Cause: The Case for Working with our Cultural Values; WWF: London, UK, 2010. Available online: http://assets.wwf.org.uk/downloads/common_cause_report.pdf (accessed on 24 July 2013).

52. Nilsson, A.; von Borgstede, C.; Biel, A. Willingness to accept climate change strategies: The effect of values and norms. J. Environ. Psychol. 2004, 24, 267-277. 
53. Karp, G.D. Values and their effect on pro-environmental behavior. Environ. Behav. 1996, 28, 111-133.

54. Kahan, D.M.; Jenkins-Smith, H.; Braman, D. Cultural cognition of scientific consensus. J. Risk Res. 2011, 14, 147-174.

55. Leiserowitz, A.A.; Maibach, E.W.; Roser-Renouf, C.; Smith, N.; Dawson, E. Climategate, public opinion, and the loss of trust. Am. Behav. Sci. 2013, 57, 818-837.

56. West, J.; Bailey, I.; Winter, M. Renewable energy policy and public perceptions of renewable energy: A cultural theory approach. Energy Policy 2010, 38, 5739-5748.

57. Dickinson, J.L.; Crain, R.; Yalowitz, S.; Cherry, T.M. How framing climate change influences citizen scientists' intentions to do something about it. J. Environ. Educ. 2013, 44, 145-158.

58. Arnell, N.W. Adapting to climate change: An evolving research programme. Clim. Change 2010, 100, 107-111.

59. Larsen, K.; Gunnarsson-Östling, U. Climate change scenarios and citizen-participation: Mitigation and adaptation perspectives in constructing sustainable futures. Habitat Int. 2009, 33, 260-266.

60. Adger, V.N. Social capital, collective action, and adaptation to climate change. Econ. Geogr. 2003, 79, 387-404.

61. Van Aalst, M.K.; Cannon, T.; Burton, I. Community level adaptation to climate change: The potential role of participatory community risk assessment. Global Environ. Change 2008, 18, 165-179.

62. Klinsky, S.; Dowlatabadi, H.; McDaniels, T. Comparing public rationales for justice trade-offs in mitigation and adaptation climate policy dilemmas. Global Environ. Change 2012, 22, 862-876.

63. Bichard, E.; Kazmierczak, A. Are homeowners willing to adapt to and mitigate the effects of climate change? Clim. Change 2012, 112, 633-654.

64. Haden, V.R.; Niles, M.T.; Lubell, M.; Perlman, J.; Jackson, L.E. Global and local concerns: What attitudes and beliefs motivate farmers to mitigate and adapt to climate change? PLoS One 2012, 7, e52882.

65. Blennow, K.; Persson, J. Climate change: Motivation for taking measure to adapt. Global Environ. Change 2009, 19, 100-104.

66. Adger, W.N.; Quinn, T.; Lorenzoni, I.; Murphy, C.; Sweeney, J. Changing social contracts in climate-change adaptation. Nature Clim. Change 2013, 3, 330-333.

(C) 2013 by the author; licensee MDPI, Basel, Switzerland. This article is an open access article distributed under the terms and conditions of the Creative Commons Attribution license (http://creativecommons.org/licenses/by/3.0/). 